\title{
Thermal study of chalcones
}

\section{Thermal decomposition of chalcone and its hydroxylated derivatives}

\author{
Marcelo Kobelnik $^{1}$ (1) - Leonardo Miziara Barboza Ferreira ${ }^{2} \cdot$ Luis Octavio Regasini $^{3} \cdot$ Luiz Antonio Dutra $^{2}$. \\ Vanderlan da Silva Bolzani ${ }^{2} \cdot$ Clóvis Augusto Ribeiro $^{2}$
}

Received: 22 August 2017 / Accepted: 30 December 2017 / Published online: 23 January 2018

(c) Akadémiai Kiadó, Budapest, Hungary 2018

\begin{abstract}
Chalcones $\alpha-\beta$-unsaturated ketones are found in large plant species. Synthesis of chalcones and its three analogues hydroxy group at $2^{\prime}, 3^{\prime}$ and $4^{\prime}$ positions (2-4) was carried out. The studies of thermal behavior were made by thermogravimetry (TG) and differential scanning calorimetry, both under oxygen and nitrogen purge gases. In addition, the kinetic evaluation was carried out under heating rates of 5,10 and $20^{\circ} \mathrm{C} \mathrm{min}^{-1}$ with sample mass of $2 \mathrm{mg}$ in open crucibles. The kinetic results obtained by TG analysis showed that the thermal behavior under oxygen shows that the functional hydroxy group substitution affects the thermal behavior of each molecule, with a gradual increase in the thermal decomposition. The activation energy $\left(\mathrm{Ea} / \mathrm{kJ} \mathrm{mol}^{-1}\right)$ showed under a nitrogen purge gas that the hydroxy group at $3^{\prime}$ position $\left(3^{\prime}\right.$-hy-chalcone compound) has a different kinetic behavior, while the chalcone under oxygen showed a low activation energy when compared with the other hydroxy groups.
\end{abstract}

Keywords Chalcones . Thermal analysis $\cdot$ Kinetic behavior

\section{Introduction}

Chalcones are $\alpha$ - $\beta$-unsaturated ketones found in large plant species besides being a precursor for the biosynthetic route of flavonoids. Natural and synthetic chalcones have attracted attention in recent years due to the diversity of biological activities exhibited as anti-inflammatory [1], anticancer [2], antifungal [3] and leishmanicidal [4]. The synthetic preparation of chalcones involves Claisen-Schmidt condensation reaction between ketone and aldehyde

Electronic supplementary material The online version of this article (https://doi.org/10.1007/s10973-017-6956-2) contains supplementary material, which is available to authorized users.

Marcelo Kobelnik

mkobelnik@gmail.com

1 Centro Universitário do Norte Paulista, UNORP, São José do Rio Preto, SP, Brazil

2 Instituto de Química, Unesp - Univ. Estadual Paulista, C.P. 355, Araraquara, SP 14800-900, Brazil

3 Departamento de Química e Ciências Ambientais, Instituto de Biociências, Letras e Ciências Exatas, Unesp - Univ. Estadual Paulista, São José do Rio Preto, SP, Brazil under acid or basic catalysis. Several other catalysis methods such as basic alumina, zinc chloride and Lewis acid such as $\mathrm{BF}_{3}$ and $\mathrm{AlCl}_{3}$ had been used [5].

The $\alpha$ - $\beta$-unsaturated bond conjugated to carbonyl acts as an electrophile and reacts with nucleophile allowing a cyclization via Michael's addition [6]. Structures containing hydroxy group in an ortho position might cyclize into flavanones and aurones. Thus, research studies the report of flavanones and aurones synthesis from chalcones and their biological activities $[7,8]$. Due to their versatile structure, several synthetic routes were reported using chalcones as a precursor for getting heterocycles such as pyrazoline, oxiran, pyran, oxopyrimidine, isoxazoline [9], derivatives of pyridine [10], derivatives of benzheteroazepine [11]. Besides this, the chalcones or 1,3-diphenyl-2-propen-1ones are considered as precursors of flavonoids and isoflavonoids, which in turn affect the taste of foods, and they are also responsible for the color of flowers, fruits and leaves [12-15]. Furthermore, others interest in compounds 1-4 are correlated to their broad medicinal relevance, which includes antitumor (1 and 2) [16-18], antibacterial (3) [19], anti-inflammatory (1) [20] and antiprotozoal (1 and 4) [21, 22]. 
Another application of these compounds relates to its in food technologies, which owing to the demand and interesting for new food antioxidants, it becomes very interesting to explore others molecules for the design, synthesis and characterization of new antioxidant agents in order to collaborate in food sciences [23-28]. Therefore, the aim of the present study was to describe thermal characterization of the chalcone (1) and it is three analogues with hydroxy group at $2^{\prime}, 3^{\prime}$ and $4^{\prime}$ position (2-4), as seen in Fig. 1. The solid compounds were characterized by thermogravimetry (TG) and differential scanning calorimetry (DSC) at three heating rates and also under nitrogen and oxygen purge gases. In addition, TG curves were also used to obtain the kinetic information about the thermal decomposition stage.

\section{Experimental}

\section{Synthesis of chalcones and their derivatives}

(Fig. 1: 1-4)

Chalcone (1) and its hydroxylated analogues (2-4) (Fig. 1) were synthesized by Claisen-Schmidt aldol condensation using protocols reported in previous studies from our group [29-31].

In a $30-\mathrm{mL}$ vial, the appropriated acetophenone $(2.5 \mathrm{mmol})$ and lithium hydroxide monohydrate $(0.5 \mathrm{mmol})$ were dissolved in methanol $(10 \mathrm{~mL})$, and the mixture was stirred at $5{ }^{\circ} \mathrm{C}$ for $10 \mathrm{~min}$. followed by the addition of benzaldehyde $(2.70 \mathrm{mmol})$. The reaction mixture was stirred at room temperature and monitored by TLC using hexane/ethyl acetate (3:1) as the mobile phase. The reaction was quenched after $24 \mathrm{~h}$ by pouring into $100 \mathrm{~mL}$ of ice-cold water. In the synthesis of these compounds as seen in Fig. 1, from 1 to $\mathbf{4}$, a stick mass was observed in the aqueous solution after quenching. Thus, the product was extracted by ethyl acetate $(3 \times 100 \mathrm{~mL})$, dried over sodium sulfate and concentrated under reduced pressure. On the other hand, the synthesis of $\mathbf{2}$ and $\mathbf{3}$ led to precipitation after quenching with cold water, and it was then filtered and crystallized with hot acetone: ethanol (1:1). For compounds $\mathbf{1} \mathbf{- 4}$, the crude products were purified by flash chromatography using hexanes: ethyl acetate as the solvent system in increasing order of polarity.

\section{Characterization by nuclear magnetic resonance (NMR)}

Chalcone (1) and its hydroxylated derivatives (2-4) were identified by ${ }^{1} \mathrm{H}$ and ${ }^{13} \mathrm{C}$ NMR spectra data obtained from Varian DRX-500 spectrometer (11.7 T). Chemical shifts $(\delta)$ were expressed in ppm. Coupling constants $(J)$ were expressed in $\mathrm{Hz}$, and splitting patterns are described as follows: $\mathrm{s}=$ singlet; br $\mathrm{s}=$ broad singlet, $\mathrm{d}=$ doublet; $\mathrm{t}=$ triplet; $\mathrm{m}=$ multiplet; $\mathrm{dd}=$ doublet of doublets. These data were extensively detailed in supporting information.

\section{Characterization by thermal analysis}

TG/DTG curves were obtained from a SDT 2960 model (TA Instruments). The evaluation of these compounds by TG analysis were carried out with sample masses around $2 \mathrm{mg}$ in an $\alpha$-alumina crucible with heating rates of 5,10 and $20{ }^{\circ} \mathrm{C} \min ^{-1}$ under nitrogen and oxygen purge gases with flow of $100 \mathrm{~mL} \mathrm{~min}{ }^{-1}$. In addition, the kinetic study was performed using the three heating rates, which have been extensively used in previous studies [32-36]. Moreover, the use of this standard in kinetic analysis is very useful for future comparisons, besides allowing the reproducing of results obtained by us and also by other research groups. The kinetic methodology used in this work was proposed by Capela and Ribeiro, which is an isoconversional method and is based on approximation to the integral temperature on the convergent of a Jacobi fraction [37-40].

The DSC curves were carried out using a calorimeter SDT 2910 model, from TA Instruments, with heating rates of $20^{\circ} \mathrm{C} \mathrm{min}{ }^{-1}$ from 30 to $400{ }^{\circ} \mathrm{C}$ under nitrogen and oxygen purge gases, with a flow of $50 \mathrm{~mL} \mathrm{~min}{ }^{-1}$.

\section{Results and discussion}

The TG/DTG evaluations of the chalcone and its hydroxylated derivatives under nitrogen and oxygen purge gases with mass of $2 \mathrm{mg}$ and heating rate of $20{ }^{\circ} \mathrm{C} \mathrm{min}-1$ are shown in Fig. $2 \mathrm{a}-\mathrm{d}$, respectively.

The chalcone (Fig. 2a) shows that the initial thermal decomposition begins to take place after $105{ }^{\circ} \mathrm{C}$ going to $250{ }^{\circ} \mathrm{C}$ for both purge gases. Also it is possible to see that in oxygen, during the mass loss, there was a decrease in the

Fig. 1 Structures of chalcone (1) and its hydroxylated derivatives (2-4)

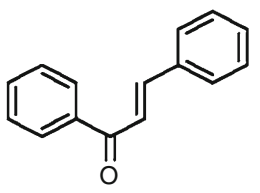

1

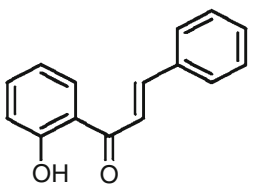

2<smiles>O=C(/C=C/c1ccccc1)c1cccc(O)c1</smiles>

3<smiles>O=C(/C=C/c1ccccc1)c1ccc(O)cc1</smiles>

4 


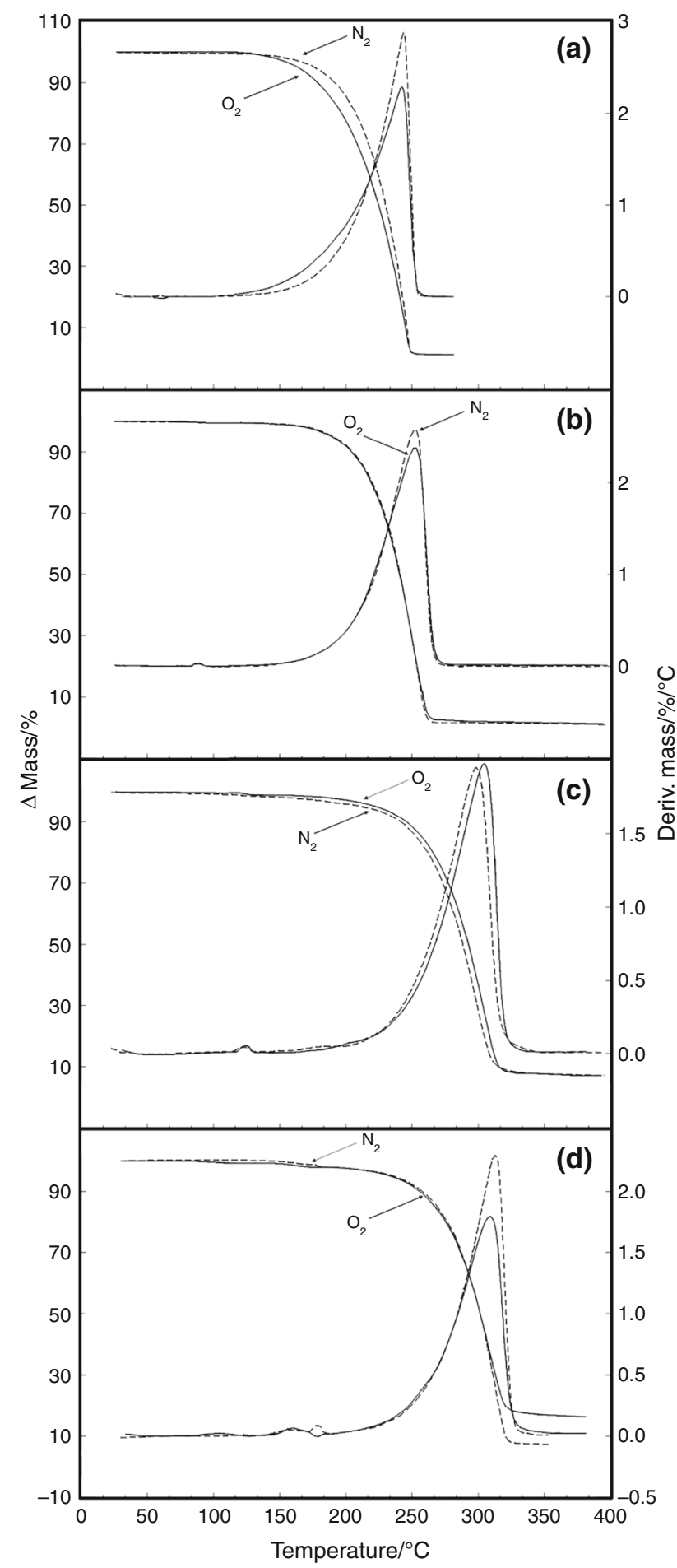

Fig. 2 TG/DTG curves of chalcone (a), 2'-hydroxychalcone (b), 3'hydroxychalcone (c) and $4^{\prime}$-hydroxychalcone (d), with mass sample around $2 \mathrm{mg}$ in $\alpha$-alumina crucible, under oxygen and nitrogen purge gases and heating rate of $20{ }^{\circ} \mathrm{C} \mathrm{min}-1$

temperatures, which is minor than that in nitrogen. The opposite effect under nitrogen gas can also be seen with $3^{\prime}$ hy-chalcone (Fig. 2c), where the reaction occurs at an interval of thermal decomposition from 150 to $326^{\circ} \mathrm{C}$.
These observed effects can be suggested as a relation of heat transfer and thermal conductivity of the gases with the samples.

The analyses with $2^{\prime}$-hy-chalcone (Fig. $2 \mathrm{~b}$ ) show that there is a similarity of thermal behavior of this sample under both purge gases. The DTG curve showed that the thermal decomposition stage occurs between 148 and $271{ }^{\circ} \mathrm{C}$, without carbonaceous residues at the end of the reaction. For the analysis of 4'-hy-chalcone (Fig. 2d), it is possible to see that the thermal decomposition is also similar, but at the end of the reaction there was a difference in behavior. Other curves were made to verify this behavior, but the results were the same, being, therefore, as suggestion a possible reaction between the sample and the oxygen. For both analyses, there was the presence of carbonaceous residues, and the mass losses were 83.75 and $92.72 \%$ under oxygen and nitrogen purge gases.

For all samples seen in Fig. 2, it is possible to observe that there is an inflection in the TG/DTG curves between the initial temperature and before the thermal decomposition. This effect was attributed to the melting of the samples, which can be seen in the DSC curves in Figs. 3 and 4, which are associated with the same temperature as the TG/ DTG curves. The DSC curves were carried out under nitrogen and oxygen purge gases, respectively, and the values of the melting points are indicated in the curves. The difference observed between the melting point analyses made with oxygen and nitrogen is attributed to the arrangement of samples in the crucible and also to the fact that samples analyzed are not a single crystal but are small different sized crystals.

For a better understanding and also for a comparison between these hydroxylated derivatives, the TG/DTG curves in oxygen and nitrogen purge gases were overlapping, as it is possible; see in Figs. 5 and 6, respectively.

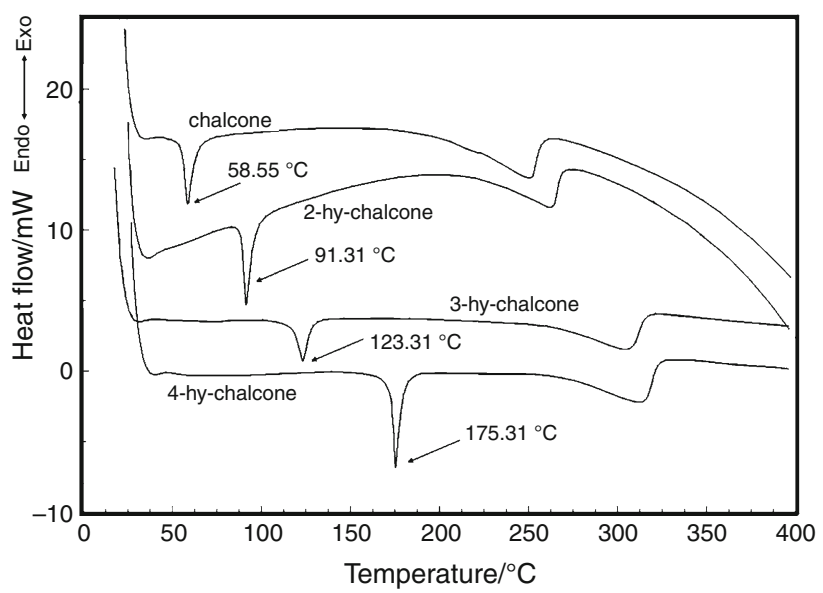

Fig. 3 DSC curves of chalcone and their hydroxylated derivatives compounds, with mass sample around $2 \mathrm{mg}$ in aluminum crucible, under nitrogen purge gas and heating rate of $20{ }^{\circ} \mathrm{C} \mathrm{min}-1$ 


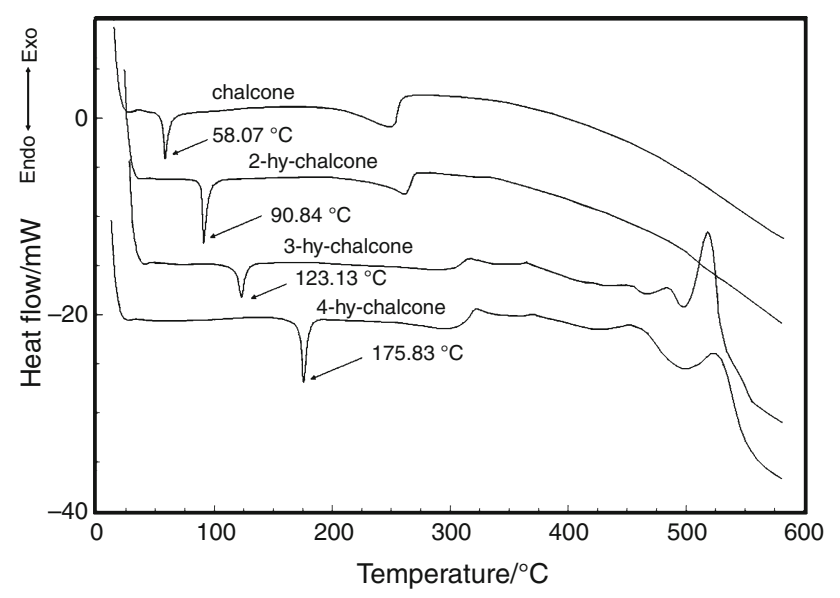

Fig. 4 DSC curves of chalcone and their hydroxylated derivatives compounds, with mass sample around $2 \mathrm{mg}$ in aluminum crucible, under oxygen purge gas and heating rate of $20^{\circ} \mathrm{C} \mathrm{min}-1$

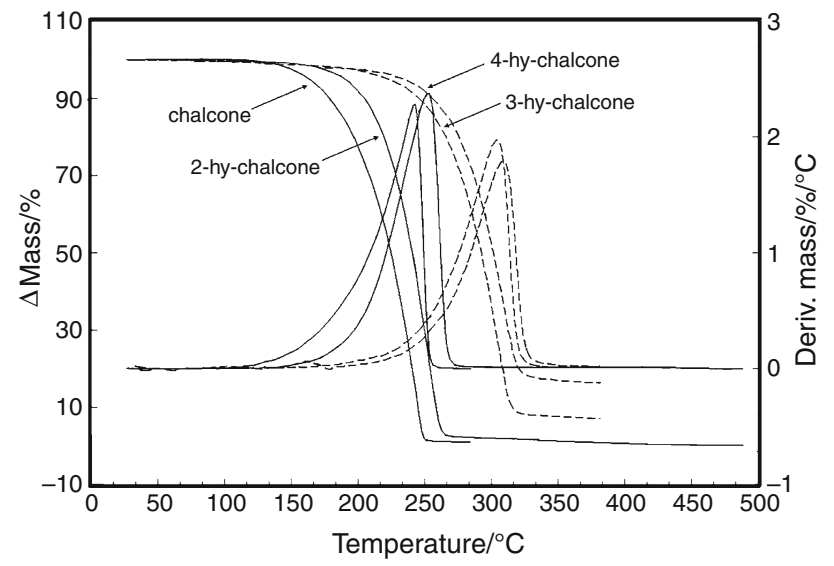

Fig. 5 TG/DTG curves of chalcone and their hydroxylated derivatives compounds, with mass sample of $2 \mathrm{mg}$ in $\alpha$-alumina crucible, under oxygen purge gas and a heating rate of $20{ }^{\circ} \mathrm{C} \mathrm{min}-1$

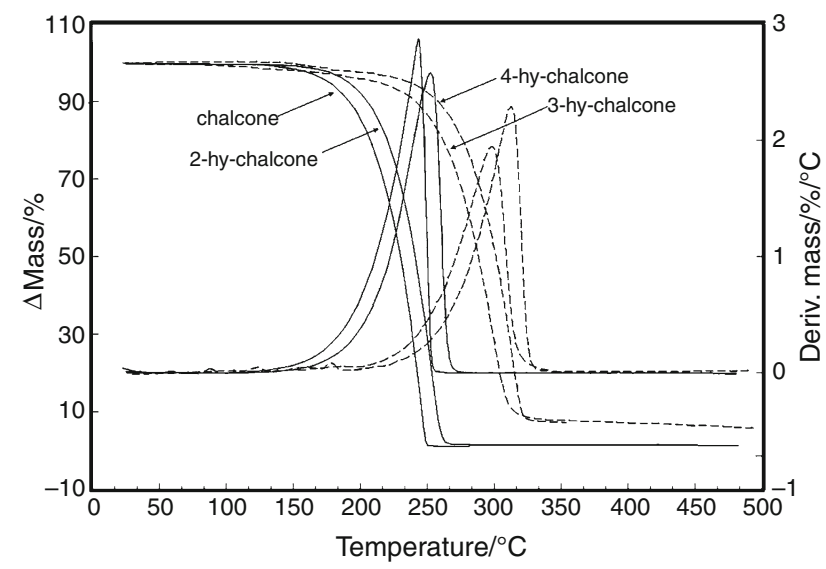

Fig. 6 TG/DTG curves chalcone and their hydroxylated derivatives compounds, with mass sample of $2 \mathrm{mg}$ in $\alpha$-alumina crucible, under nitrogen purge gas and a heating rate of $20{ }^{\circ} \mathrm{C} \mathrm{min}-1$
The thermal behavior in oxygen shows that the functional hydroxy group substitution present at each position in the chalcone affects the thermal conductivity of the molecule, because there was a gradual increase in the thermal decomposition temperature. In addition, the thermal decomposition at $3^{\prime}$ and $4^{\prime}$-hy-chalcone shows a difference in carbonaceous residues generated at the end of the reaction. However, this fact is not seen for the chalcone and $2^{\prime}$-hy-chalcone. For nitrogen analysis, the thermal behavior is similar to that seen in oxygen purge gas, except that there were no carbonaceous residues generated at the end of the thermal decomposition.

\section{Kinetic evaluation}

Figure 7 shows the overlapping of the three TG curves with heating rates of 5,10 and $20{ }^{\circ} \mathrm{C} \mathrm{min}-1$ of chalcone as a set of curves to obtain the kinetic data. The other compounds were not placed because they follow the same tendency of displacement of the heating rates. Moreover, in others works, we have used a pattern of at least three TG curves for kinetic behavior analysis, as suggested by the ICTAC committee [40-45]. In a similar way, for all curves (even for those not shown), the result shows that there were no changes to the thermal behavior, and therefore the profiles of curves remained the same, that is, without apparent overlapping of thermal decomposition reactions.

Table 1 shows the average of the values of activation energy (with a coefficient variation), the linear correlation obtained for compounds and the temperature intervals in DTG curves that were used for kinetic evaluation. The low activation energy values obtained for these compounds indicate the dependence on temperature, which implies that low temperatures are required for thermal decomposition.

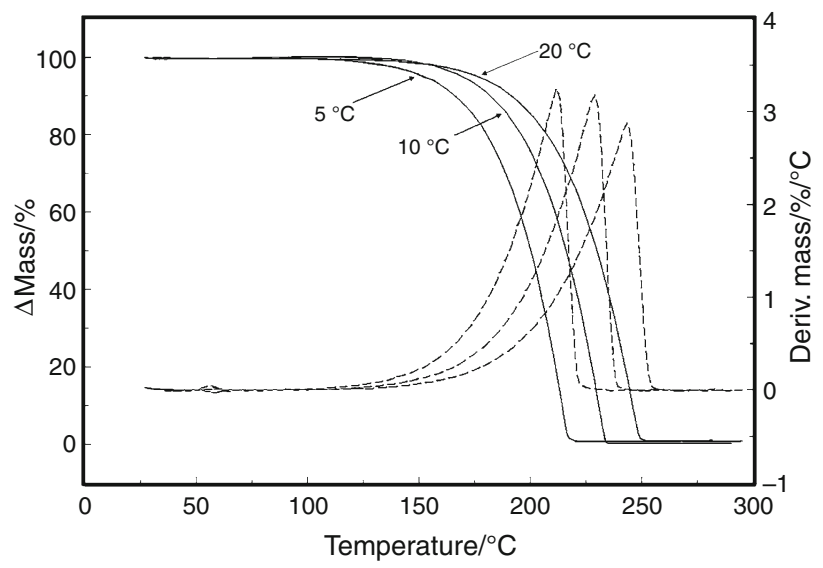

Fig. 7 TG/DTG curves of chalcone with sample mass around $2 \mathrm{mg}$ in $\alpha$-alumina crucible, under nitrogen purge gas and a heating rates of 5 , 10 and $20{ }^{\circ} \mathrm{C} \min ^{-1}$ 

correlation coefficient $(r)$ and curves for thermal decomposition
Table $1 E_{\mathrm{a}}\left(\mathrm{kJ} \mathrm{mol}^{-1}\right)$, temperature intervals of DTG

\begin{tabular}{|c|c|c|c|c|}
\hline Compounds & Purge gases & Temperature ranges (DTG curves) & $* E_{\mathrm{a}} / \mathrm{kJ} \mathrm{mol}^{-1}$ & $*_{r}$ \\
\hline \multirow[t]{2}{*}{ Chalcone } & Nitrogen & $\begin{array}{l}\left(5^{\circ} \mathrm{C}\right) 121-225^{\circ} \mathrm{C} \\
\left(10^{\circ} \mathrm{C}\right) 136-236{ }^{\circ} \mathrm{C} \\
\left(20^{\circ} \mathrm{C}\right) 148-257^{\circ} \mathrm{C}\end{array}$ & $87.76 \pm 0.04$ & 0.99646 \\
\hline & Oxygen & $\begin{array}{l}\left(5^{\circ} \mathrm{C}\right) 105-219^{\circ} \mathrm{C} \\
\left(10^{\circ} \mathrm{C}\right) 114-230{ }^{\circ} \mathrm{C} \\
\left(20^{\circ} \mathrm{C}\right) 121-255^{\circ} \mathrm{C}\end{array}$ & $55.72 \pm 0.01$ & 0.96343 \\
\hline \multirow[t]{2}{*}{ 2'-Hydroxychalcone } & Nitrogen & $\begin{array}{l}\left(5^{\circ} \mathrm{C}\right) 137-243{ }^{\circ} \mathrm{C} \\
\left(10^{\circ} \mathrm{C}\right) 152-256{ }^{\circ} \mathrm{C} \\
\left(20^{\circ} \mathrm{C}\right) 162-272{ }^{\circ} \mathrm{C}\end{array}$ & $85.97 \pm 0.02$ & 0.99661 \\
\hline & Oxygen & $\begin{array}{l}\left(5^{\circ} \mathrm{C}\right) 122-237{ }^{\circ} \mathrm{C} \\
\left(10^{\circ} \mathrm{C}\right) 150-262{ }^{\circ} \mathrm{C} \\
\left(20^{\circ} \mathrm{C}\right) 168-272{ }^{\circ} \mathrm{C}\end{array}$ & $81.56 \pm 0.04$ & 0.99646 \\
\hline \multirow[t]{2}{*}{ 3'-Hydroxychalcone } & Nitrogen & $\begin{array}{l}\left(5^{\circ} \mathrm{C}\right) 181-290{ }^{\circ} \mathrm{C} \\
\left(10^{\circ} \mathrm{C}\right) 200-314{ }^{\circ} \mathrm{C} \\
\left(20^{\circ} \mathrm{C}\right) 211-330^{\circ} \mathrm{C}\end{array}$ & $106.45 \pm 0.02$ & 0.99964 \\
\hline & Oxygen & $\begin{array}{l}\left(5^{\circ} \mathrm{C}\right) 168-290{ }^{\circ} \mathrm{C} \\
\left(10^{\circ} \mathrm{C}\right) 187-309{ }^{\circ} \mathrm{C} \\
\left(20^{\circ} \mathrm{C}\right) 201-329^{\circ} \mathrm{C}\end{array}$ & $85.76 \pm 0.01$ & 0.99694 \\
\hline \multirow[t]{2}{*}{ 4'-Hydroxychalcone } & Nitrogen & $\begin{array}{l}\left(5^{\circ} \mathrm{C}\right) 186-299{ }^{\circ} \mathrm{C} \\
\left(10^{\circ} \mathrm{C}\right) 200-319^{\circ} \mathrm{C} \\
\left(20{ }^{\circ} \mathrm{C}\right) 221-337^{\circ} \mathrm{C}\end{array}$ & $85.77 \pm 0.01$ & 0.99895 \\
\hline & Oxygen & $\begin{array}{l}\left(5^{\circ} \mathrm{C}\right) 194-302{ }^{\circ} \mathrm{C} \\
\left(10{ }^{\circ} \mathrm{C}\right) 203-315^{\circ} \mathrm{C} \\
\left(20^{\circ} \mathrm{C}\right) 218-334{ }^{\circ} \mathrm{C}\end{array}$ & $91.20 \pm 0.04$ & 0.99547 \\
\hline
\end{tabular}

*Average

The relation between the activation energy versus conversion degree under nitrogen and oxygen purge gases is shown in Figs. 8 and 9, respectively. As can be seen in the nitrogen purge gas, the kinetic behaviors are linear, with a more pronounced difference for $3^{\prime}$-hydroxychalcone, while for analysis under oxygen purge gas, the major difference occurs for chalcone. It is important to note that the kinetic behavior in oxygen follows a pattern of minor activation energy for chalcone to major activation energy for 4 '-hychalcone. The minor activation energy of chalcone under oxygen is probably due to the weak intermolecular

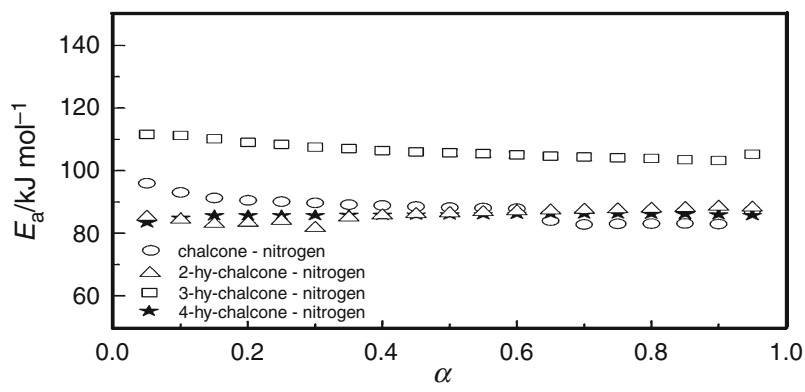

Fig. 8 Calculated $E_{\mathrm{a}} / \mathrm{kJ} \mathrm{mol}^{-1}$ as a function of $\alpha$ for the transition phase stage under nitrogen purge gas

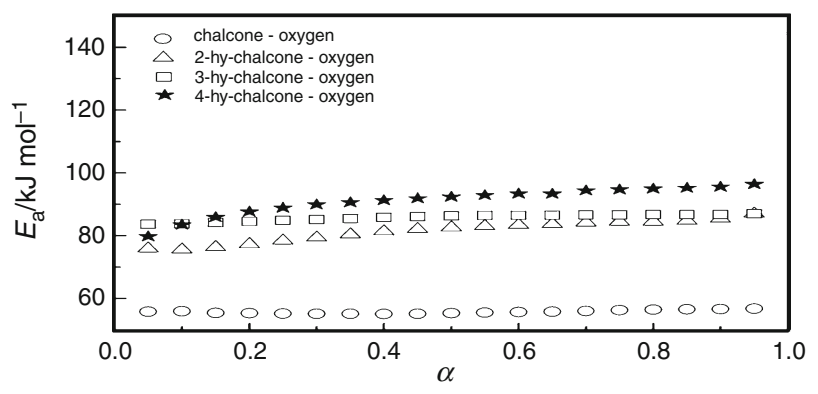

Fig. 9 Calculated $E_{\mathrm{a}} / \mathrm{kJ} \mathrm{mol}^{-1}$ as a function of $\alpha$ for the transition phase stage under oxygen purge gas

interactions, while for the other molecules this interaction is similar, hence the motive of the closest activation energies. However, under nitrogen, the $3^{\prime}$-hy-chalcone has major value of activation energy, which stands out from the others. This behavior is a probable indication that this molecule has an intermolecular interaction greater than the others. In previous papers about the synthesis and thermal characterization of flavanone and $6^{\prime}$-hydroxyflavanone flavanones, it was possible to see that there was an alteration in the activation energy under nitrogen purge gas with 
hydroxy group in flavanone, with the increase in the activation energy to a higher value [26].

\section{Conclusions}

In the present study, we evaluated four chalcones by thermogravimetry (TG), derivative thermogravimetry (DTG) and differential scanning calorimetry (DSC), which showed the comparisons of thermal behavior under nitrogen and oxygen purge gases. Besides, the present study on these molecules showed that they have a thermal behavior without presenting large variations of overlapping reactions, which can be used as analysis standards. The thermal decomposition showed that these compounds had homogeneous processes, and therefore they provide a good and linear behavior for kinetic study. The kinetic evaluation showed that the third position of the hydroxy group at aromatic ring affects the kinetic behavior, as seen in the nitrogen purge gas, but the analysis under the oxygen indicates that the position little affects the kinetic behavior.

\section{References}

1. Zeraik ML, Ximenes VF, Regasini LO, Dutra LA, Silva DH, Fonseca LM, Coelho D, Machado SA, Bolzani VS. 4'Aminochalcones as novel inhibitors of the chlorinating activity of myeloperoxidase. Curr Med Chem. 2012;19:5405-13.

2. Vogel S, Barbic M, Jurgenliemk G, Heilmann J. Synthesis, cytotoxicity, anti-oxidative and anti-inflammatory activity of chalcones and influence of A-ring modifications on the pharmacological effect. Eur J Med Chem. 2010;45:2206-13.

3. Gupta D, Jain DK. Chalcone derivatives as potential antifungal agents: synthesis, and antifungal activity. J Adv Pharm Technol Res. 2015;6:114-7.

4. Passalacqua TG, Dutra LA, de Almeida L, Velásquez AM, Torres FA, Yamasaki PR, Santos MB, Regasini LO, Michels PA, Bolzani Vda S, Graminha MA. Synthesis and evaluation of novel prenylated chalcone derivatives as anti-leishmanial and anti-trypanosomal compounds. Bioorg Med Chem Lett. 2015;25:3342-5.

5. Kumara S, Lambab MS, Makrandia JK. An efficient green procedure for the synthesis of chalcones using C-200 as solid support under grinding conditions. Green Chem Lett Rev. 2008;1:123-5.

6. Suwito H, Mustofa J, Kristanti AN, Puspaningsih NNT. Chalcones: synthesis, structure diversity and pharmacological aspects. J Chem Pharm Res. 2014;6:1076-88.

7. Harwood LM, Loftus GC, Oxford A, Thomson C. An improved procedure for cyclisation of chalcones to flavanones using celite supported potassium fluoride in methanol: total synthesis of bavachinin. Synth Commun. 1990;20:649-57.

8. Detsi A, Majdalani M, Kontogiorgis CA, Hadjipavlou-Litina D, Kefalas P. Natural and synthetic 20-hydroxy-chalcones and aurones: synthesis, characterization and evaluation of the antioxidant and soybean lipoxygenase inhibitory activity. Bioorg Med Chem. 2009;17:8073-85.

9. Fathalla OA, Awad SM, Mohamed MS. Synthesis of new 2-thiouracil-5-sulphonamide derivatives with antibacterial and antifungal activity. Arch Pharm Res. 2005;28(11):1205-12.
10. Ramiz MMM, El-Sayed WA, El-Tantawy AI, Abdel-Rahman AAH. Antimicrobial activity of new 4,6-disubstituted pyrimidine, pyrazoline, and pyran derivatives. Arch Pharm Res. 2010;33:647-54.

11. Braun RU, Zeitler K, Mueller TJJ. A novel 1,5-benzoheteroazepine synthesis via a one-pot coupling-isomerizationcyclocondensation sequence. Org Lett. 2000;2:4181-4.

12. Harborne JB, Williams CA. Advances in flavonoid research since 1992. Phytochemistry. 2000;55:481-504.

13. Gronquist M, Bezzerides A, Attygalle A, Meinwald J, Eisner M, Eisner T. Attractive and defensive function of the ultraviolet pigments of a flower (Hypericum calycinum). Proc Natl Acad Sci. 2001;98:13745-50.

14. Modzelewska A, Pettit C, Achanta G, Davidson NE, Huang P, Khan SR. Anticancer activities of novel chalcone and bis-chalcone derivatives. Bioorg Med Chem. 2006;14:3491-5.

15. Patil CB, Mahajan SK, Katti SA. Chalcone: a versatile molecule. J Pharm Sci Res. 2009;1(3):11-22.

16. Mai CW, Yaeghoobi M, Abd-Rahman N, Kang YB, Pichika MR. Chalcones with electron-withdrawing and electron-donating substituents: anticancer activity against TRAIL resistant cancer cells, structure-activity relationship analysis and regulation of apoptotic proteins. Eur J Med Chem. 2014;77:378-87.

17. Wu Wang FW, Wang SQ, Zhao BX, Miao JY. Discovery of $2^{\prime}$ hydroxychalcones as autophagy inducer in A549 lung cancer cells. Org Biomol Chem. 2014;12:3062-70.

18. Shin SY, Jung H, Ahn S, Hwang D, Yoon H, Hyun J, Yong Y, Cho HJ, Koh D, Lee YH, Lim Y. Polyphenols bearing cinnamaldehyde scaffold showing cell growth inhibitory effects on the cisplatin-resistant A2780/Cis ovarian cancer cells. Bioorg Med Chem. 2014;22:1809-20.

19. Silva WA, Andrade CKZ, Napolitano HB, Vencato I, Lariucci C, Castro MRC, Camargo AJ. Biological and structure-activity evaluation of chalcone derivatives against bacteria and fungi. J Braz Chem Soc. 2013;24:133-44.

20. Ventura TLB, Calixto SD, Vieira BAA, Souza AMT, Mello MVP, Rodrigues CR, Miranda LSM, Souza ROMA, Leal ICR, Lasunskaia EB. Antimycobacterial and anti-inflammatory activities of substituted chalcones focusing on an anti-tuberculosis dual treatment approach. Molecules. 2015;20:8072-93.

21. Lunardi F, Guzela M, Rodrigues A, Correa R, Eger IM, Steindel M, Grisard EC, Assreuy J, Calixto J, Santos ARS. Trypanocidal and leishmanicidal properties of substitution-containing chalcones. Antimicrob Agents Chemother. 2003;47:1449-51.

22. Liu M, Wilairat P, Croft SL, Tand ALC, Goa ML. Structureactivity relationships of antileishmanial and antimalarial chalcones. Bioorg Med Chem. 2003;11:2729-38.

23. Dziedzic SZ, Hudson BJF. Phenolic acids and related compounds as antioxidants for edible oils. Food Chem. 1984;14:45-51.

24. Hwang HS, Winkler-Moser JK. Food additives reducing volatility of antioxidants at frying temperature. J Am Oil Chem Soc. 2014;91:1745-61.

25. Chao M, Li W, Wang X. Thermal decomposition kinetics and anti-oxidation performance of commercial antioxidants. J Therm Anal Calorim. 2015;120:1921-8.

26. Souza AL, Martínez FP, Ferreira SB, Kaiser CR. A complete evaluation of thermal and oxidative stability of chia oil. J Therm Anal Calorim. 2017;130:1307-15.

27. Forero-Doria O, García MF, Vergara CE, Guzman L. Thermal analysis and antioxidant activity of oil extracted from pulp of ripe avocados. J Therm Anal Calorim. 2017;130:959-66.

28. John J, Devi RS, Balachandran S, Dinesh Babu KV. Synthesis, spectral characterization and thermal analysis of rubrocurcumin and its analogues. J Therm Anal Calorim. 2017;130:2301-14.

29. Passalacqua TG, Dutra LA, de Almeida L, Velasquez AM, Torres FA, Yamasaki PR, dos Santos MB, Regasini LO, Michels PA, 
Bolzani VS, Graminha MA. Synthesis and evaluation of novel prenylated chalcone derivatives as anti-leishmanial and anti-trypanosomal compounds. Bioorg Med Chem Lett. 2015;25:3342-5.

30. Passalacqua TG, Torres FA, Nogueira CT, de Almeida L, Del Cistia ML, dos Santos MB, Regasini LO, Graminha MA, Marchetto R, Zottis A. The $2^{\prime}, 4^{\prime}$-dihydroxychalcone could be explored to develop new inhibitors against the glycerol-3-phosphate dehydrogenase from Leishmania species. Bioorg Med Chem Lett. 2015;25:3564-8.

31. Zeraik ML, Ximenes VF, Regasini LO, Dutra LA, Silva DH, Fonseca LM, Coelho D, Machado SA, Bolzani VS. 4'Aminochalcones as novel inhibitors of the chlorinating activity of myeloperoxidase. Curr Med Chem. 2012;19:5405-13.

32. Ferreira LMB, Kobelnik M, Regasini LO, Dutra LA, Bolzani VS, Ribeiro CA. Synthesis and evaluation of the thermal behavior of flavonoids: thermal decomposition of flavanone and 6-hydroxyflavanone. J Therm Anal Calorim. 2017;127:1605-10.

33. Marques MR, Fontanari GG, Kobelnik M, Freitas RAMS, Areas JAG. Effect of cooking on the thermal behavior of the cowpea bean oil (Vigna unguiculata L. Walp). J Therm Anal Calorim. 2015;120:289-96.

34. Kobelnik M, Fontanari GG, Marques MR, Ribeiro CA, Crespi MS. Thermal behavior and chromatographic characterization of oil extracted from the nut of the Butia (Butia capitata). J Therm Anal Calorim. 2016;123:2517-22.

35. Kobelnik M, Fontanari GG, Freitas RAMS, Figueiredo AG, Ribeiro CA. Study of the thermal behavior of bicuíba oil (Virola bicuhyba). Therm Anal Calorim. 2014;115:2107-13.

36. Dias DS, Crespi MS, Ribeiro CA, Kobelnik M. Evaluation by thermogravimetry of the interaction of the poly(ethylene terephthalate) with oil-based paint. Eclét Quím. 2015;40:77-85.

37. Capela JMV, Capela MV, Ribeiro CA. Nonisothermal kinetic parameters estimated using nonlinear regression. J Math Chem. 2009;45:769-75.
38. Fontanari GG, Kobelnik M, Marques MR, Arêas JAG, Franzin BT, Pastre IA, Fertonani FL. Thermal and kinetic studies of white lupin (Lupinus albus) oil. J Therm Anal Calorim. 2017. https:// doi.org/10.1007/s10973-017-6468-0.

39. Kobelnik M, Fontanari GG, Ribeiro CA, Crespi MS. Evaluation of thermal behavior and chromatographic characterization of oil extracted from seed of Pittosporum undulatum. J Therm Anal Calorim. 2017. https://doi.org/10.1007/s10973-017-6763-9.

40. Findorák R, Frohlichová M, Legemza J, Findorákova L. Thermal degradation and kinetic study of sawdusts and walnut shells via thermal analysis. J Therm Anal Calorim. 2016;125:689-94.

41. Shin S, Im SI, Nho NS, Lee KB. Kinetic analysis using thermogravimetric analysis for nonisothermal pyrolysis of vacuum residue. J Therm Anal Calorim. 2016;126:933-41.

42. Mendonca ARV, Selene MA, de Souza GU, Valle JAB, de Souza AAU. Thermogravimetric analysis and kinetic study of pyrolysis and combustion of residual textile sludge. J Therm Anal Calorim. 2015;121:807-14.

43. Chen T, Wu W, Wu J, Cai J, Wu J. Determination of the pseudocomponents and kinetic analysis of selected combustible solid wastes pyrolysis based on Weibull model. J Therm Anal Calorim. 2016;126:1899-909.

44. Wang H, Zhang J, Wang G, Xu R, Zhang P, Liu S, Song T. Characteristics and kinetic analysis of co-combustion of brown coal and anthracite. J Therm Anal Calorim. 2016;126:447-54.

45. Kobelnik M, Ribeiro CA, Dias DS, Crespi MS. Estudo do comportamento cinético da decomposição térmica do composto de 2-metoxibenzalpiruvato de manganês no estado sólido. Rev Unorp. 2012;3:28. 